\title{
Crop systems and topdressing nitrogen on grain yield and technological attributes of common bean under no-tillage ${ }^{1}$
}

\author{
Fábio Luíz Checchio Mingotte ${ }^{2}$, Leandro Borges Lemos², \\ Celso Antônio Jardim², Domingos Fornasieri Filho²
}

\section{ABSTRACT}

Common bean has been the main crop in succession to corn and Brachiaria in no-tillage systems, in the Brazilian Savannah. This study aimed to evaluate the influence of crop systems and topdressing nitrogen on grain yield and technological attributes of common bean under no-tillage. A randomized block design, in a split-plot arrangement, with four replications, was used. The plots consisted of three crop systems (corn in sole crop, corn + Urochloa ruziziensis intercropped and $U$. ruziziensis in sole crop) and the subplots by five nitrogen rates $\left(0 \mathrm{~kg} \mathrm{ha}^{-1}, 40 \mathrm{~kg} \mathrm{ha}^{-1}, 80 \mathrm{~kg} \mathrm{ha}^{-1}, 120 \mathrm{~kg} \mathrm{ha}^{-1}\right.$ and $\left.160 \mathrm{~kg} \mathrm{ha}^{-1}\right)$. There is interaction between predecessor cropping systems and $\mathrm{N}$ rates for grain yield, milling efficiency specifically on sieve 13 , as well as for the grain hydration ratio. Increasing topdressing $\mathrm{N}$ rates applied on common bean in succession to corn in sole crop promote increases in grain yield, resulting in a milling efficiency in the oblong-hole sieve 14 higher than in the other crop systems evaluated. The increase of the topdressing $\mathrm{N}$ rates applied on common bean in succession to corn and $U$. ruziziensis in sole crops or intercropped does not influence the time for maximum hydration of the grains, but reduces their cooking time, mainly in succession to $U$. ruziziensis and corn in sole crops.

KEY-WORDS: Phaseolus vulgaris, milling efficiency, crude protein content, cooking time, maximum hydration time.

\section{INTRODUCTION}

Common bean presents characteristics that make its consumption advantageous, due to the high protein and energy contents, besides the beneficial effects provided by the high contents of fiber, iron and other minerals, carbohydrates and presence of B-complex vitamins. In this scenario, disseminating information about the technological attributes of the grains is essential for an increase

\section{RESUMO}

Sistemas de cultivo e nitrogênio em cobertura na produtividade e atributos tecnológicos de feijoeiro sob plantio direto

O feijoeiro tem sido a principal cultura em sucessão ao milho e à braquiária em sistema plantio direto, no Cerrado. Objetivou-se avaliar os efeitos de sistemas de cultivo e nitrogênio em cobertura na produtividade e atributos tecnológicos de feijoeiro sob plantio direto. Utilizou-se delineamento em blocos casualizados, em parcelas subdivididas, com quatro repetições. As parcelas foram compostas por três sistemas de cultivo (milho exclusivo, milho + Urochloa ruziziensis e $U$. ruziziensis exclusiva) e as subparcelas por cinco doses de nitrogênio $\left(0 \mathrm{~kg} \mathrm{ha}^{-1}, 40 \mathrm{~kg} \mathrm{ha}^{-1}, 80 \mathrm{~kg} \mathrm{ha}^{-1}, 120 \mathrm{~kg} \mathrm{ha}^{-1} \mathrm{e}\right.$ $\left.160 \mathrm{~kg} \mathrm{ha}^{-1}\right)$. Ocorre interação entre sistemas de cultivo antecessores e doses de $\mathrm{N}$ para a produtividade de grãos, renda de benefício especificamente na peneira 13, bem como para a relação de hidratação. Doses crescentes de N no feijoeiro em sucessão ao milho exclusivo promovem acréscimos na produtividade de grãos, resultando em renda de benefício na peneira oblonga 14 superior às dos demais sistemas de cultivo avaliados. $\mathrm{O}$ aumento das doses de $\mathrm{N}$ em cobertura no feijoeiro em sucessão ao milho e $U$. ruziziensis cultivados exclusivamente e em consórcio não influencia o tempo para máxima hidratação dos grãos, mas reduz o seu tempo de cozimento, principalmente em sucessão a U. ruziziensis e milho em cultivos exclusivos.

PALAVRAS-CHAVE: Phaseolus vulgaris, renda de benefício, teor de proteína bruta, tempo para cozimento, tempo para máxima hidratação.

in its consumption, both fresh and industrialized (Farinelli \& Lemos 2010, Mingotte et al. 2013, Amaral et al. 2016).

The main parameters that guide the technological attributes of common bean grains are the coat size, shape and color, protein content, amino acid balance, cooking time and hydration capacity. However, besides the productive potential, common bean technological attributes are also determined by the genotype influence of the environment and

1. Received: Jul. 14, 2018. Accepted: Dec. 21, 2018. Published: Jun. 18, 2019. DOI: 10.1590/1983-40632019v4954003.

2. Universidade Estadual Paulista, Faculdade de Ciências Agrárias e Veterinárias, Departamento de Produção Vegetal,

Jaboticabal, SP, Brasil.E-mail/ORCID: flcmingotte@gmail.com/0000-0003-0383-7802, leandro.lemos@unesp.br/ 0000-0003-1781-1267, celso.aj@bol.com.br/0000-0003-4147-378X, fornasieri@fcav.unesp.br/0000-0001-6979-9170. 
the interaction between genotype and environment (Carbonell et al. 2003, Dalla Corte et al. 2003).

Concerning the environment, the sustainability of crop systems in tropical regions, mainly under high temperatures and excessive rainfall in the summer and dry periods in the winter, has already been discussed (Mingotte \& Lemos 2018). In these regions, the greatest challenge lies in the formation and maintenance of straw, due to the high rate of decomposition of plant residues and the difficulty of their off-season production. In order to overcome this situation, it has been recommended to cultivate plant species that provide a high amount of straw with a balanced carbon/nitrogen ratio (Mingotte \& Lemos 2018). For these reasons, the intercropping of corn and Urochloa sp. in the Brazilian Savannah has stood out as a sustainable alternative in the recovery of degraded pastures, allowing success in the implementation of no-tillage and integrated croplivestock-forest systems (Mingotte \& Lemos 2018).

Especially in the no-tillage system, changes in the nitrogen $(\mathrm{N})$ dynamics may occur in the soil due to the action of biotic and abiotic factors, altering the processes of its use by plants in a different way from the conventional system. The $\mathrm{N}$ absorbed by plants combines with carbon skeletons in the production of amino acids, resulting in proteins that are stored in plant tissues. In the grain-filling stage, these reserves are broken, translocated and stored in these organs in the form of proteins and amino acids. In addition, $\mathrm{N}$ fertilization, besides promoting increases in yield (Cunha et al. 2015, Soratto et al. 2017), also stands out in the increase of grain protein content (Silva et al. 2006, Farinelli \& Lemos 2010, Amaral et al. 2016).

Regarding technological attributes, it is noteworthy that there are few studies relating the influence of cropping systems and fertilizer use (especially $\mathrm{N}$ ) on the technological quality of common bean grains. In this line, Silva et al. (2006), when evaluating the effect of topdressing $\mathrm{N}\left(0 \mathrm{~kg} \mathrm{ha}^{-1}\right.$, $30 \mathrm{~kg} \mathrm{ha}^{-1}, 60 \mathrm{~kg} \mathrm{ha}^{-1}$ and $\left.120 \mathrm{~kg} \mathrm{ha}^{-1}\right)$ and foliar Mo application $\left(0 \mathrm{~g} \mathrm{ha}^{-1}\right.$ and $\left.80 \mathrm{~g} \mathrm{ha}^{-1}\right)$ on the yield and technological characteristics of bean grains (Pérola cultivar) in the no-tillage system, did not verify effects on the yield, but only on the technological attributes.

The crude protein content, cooking time and time for maximum hydration of grains increase with the use of topdressing $\mathrm{N}$ rates, the cooking time is longer as topdressing $\mathrm{N}$ rates increase with the use of molybdenum and the use of molybdenum via leaves leads to the shortest time for maximum grain hydration (Silva et al. 2006). In another study, Farinelli \& Lemos (2010) verified the influence of soil management (tillage and no-tillage systems) and topdressing $\mathrm{N}$ rates $\left(0 \mathrm{~kg} \mathrm{ha}^{-1}, 40 \mathrm{~kg} \mathrm{ha}^{-1}, 80 \mathrm{~kg} \mathrm{ha}^{-1}\right.$, $120 \mathrm{~kg} \mathrm{ha}^{-1}$ and $160 \mathrm{~kg} \mathrm{ha}^{-1}$; urea source) on the yield and grain technological attributes of Pérola common bean, where the $\mathrm{N}$ fertilization promoted an increase in the crude protein content, and the soil management systems and topdressing $\mathrm{N}$ rates influenced the cooking time differently. For the two soil management systems, the application of topdressing $\mathrm{N}$ rates caused an increase in the time for maximum grain hydration up to the amount of $120 \mathrm{~kg} \mathrm{ha}^{-1}$. Thus, obtaining technical information regarding $\mathrm{N}$ fertilization aiming not only at increasing the yield potential, but also its association with the grain technological attributes, should be recommended, with emphasis on the protein content, cooking time and hydration capacity (Carbonell et al. 2003, Rodrigues et al. 2005, Amaral et al. 2016).

Thus, this study aimed to evaluate the yield and technological quality of common bean in succession to corn and $U$. ruziziensis, as a function of the application of $\mathrm{N}$ rates in no-tillage system.

\section{MATERIAL AND METHODS}

The experiment was carried out at the Universidade Estadual Paulista, in Jaboticabal, São Paulo state, Brazil $\left(21^{\circ} 15^{\prime} 22^{\prime}\right.$ 'S, $48^{\circ} 18^{\prime} 58^{\prime \prime} \mathrm{W}$ and $595 \mathrm{~m}$ of altitude), in Eutrophic Red Latosol. The climate of the region, according to the Köppen's classification, is Aw, humid tropical with a rainy season in the summer and a dry season in the winter.

The experiment was conducted in an experimental area in the second year after no-tillage system implementation previously cultivated with annual crops (corn, common bean and rice) for at least 15 years in the conventional sowing system, with some fallow periods.

The results of the soil chemical analysis, obtained before the common bean was planted, at the depth of $0-20 \mathrm{~cm}$, were: $\mathrm{P}$ (resin) $=55 \mathrm{mg} \mathrm{dm}^{-3}$; $\mathrm{OM}=19 \mathrm{~g} \mathrm{~kg}^{-1} ; \mathrm{pH}\left(\mathrm{CaCl}_{2}\right)=5.2 ; \mathrm{K}=6 \mathrm{mmol}_{\mathrm{c}} \mathrm{dm}^{-3}$; $\mathrm{Ca}=27 \mathrm{mmol}_{\mathrm{c}} \mathrm{dm}^{-3} ; \mathrm{Mg}=11 \mathrm{mmol}_{\mathrm{c}} \mathrm{dm}^{-3} ; \mathrm{H}+\mathrm{Al}=$ $34 \mathrm{mmol}_{\mathrm{c}} \mathrm{dm}^{-3} ; \mathrm{CEC}=78 \mathrm{mmol}_{\mathrm{c}} \mathrm{dm}^{-3}$; base saturation $=$ $57 \%$. 
A randomized block design, in a split-plot arrangement, with four replications, was used. The plots were represented by three summer cropping systems (2009/2010 crop season) consisting of corn and $U$. ruziziensis in sole crops and intercropped, preceding the common bean. The subplots consisted of five topdressing $\mathrm{N}$ rates $\left(0 \mathrm{~kg} \mathrm{ha}^{-1}, 40 \mathrm{~kg} \mathrm{ha}^{-1}\right.$, $80 \mathrm{~kg} \mathrm{ha}^{-1}, 120 \mathrm{~kg} \mathrm{ha}^{-1}$ and $\left.160 \mathrm{~kg} \mathrm{ha}^{-1}\right)$, using urea as source. The rate of $80 \mathrm{~kg} \mathrm{ha}^{-1}$ refers to the high-response class, because it is an irrigated crop and cultivated after grasses. The topdressing $\mathrm{N}$ fertilization was applied in a continuous strip, $10 \mathrm{~cm}$ away from the planting row, without incorporation, at the beginning of the phenological stage V4, characterized by the presence of the third fully developed trifoliate leaf in $50 \%$ of the plants, followed by irrigation with water depth of $10 \mathrm{~mm}$. Each subplot consisted of six 5-m-long rows, considering the four central rows for evaluations and disregarding $0.5 \mathrm{~m}$ on each end.

The summer crops were sown on 17 December 2009, using the early cycle hybrid DKB 390 YG, at a spacing of $0.90 \mathrm{~m}$. The mineral fertilization at sowing consisted of $28 \mathrm{~kg} \mathrm{ha}^{-1}$ of N, $70 \mathrm{~kg} \mathrm{ha}^{-1}$ of $\mathrm{P}_{2} \mathrm{O}_{5}$ and $70 \mathrm{~kg} \mathrm{ha}^{-1}$ of $\mathrm{K}_{2} \mathrm{O}$. The total of $120 \mathrm{~kg} \mathrm{ha}^{-1}$ of $\mathrm{N}$ were applied at the V6 development stage, without incorporation and with a $15 \mathrm{~mm}$ water depth application shortly after fertilization. The corn harvest was carried out manually on 05 May 2010. The forage species used was $U$. ruziziensis, which shows sub-erect growth and stems with decumbent base producing roots at the nodes in contact with the soil. In the intercropping system, the forage was sown in double rows by applying a crop value of 400 points, equivalent to $7.5 \mathrm{~kg} \mathrm{ha}^{-1}$, and with $0.45 \mathrm{~m}$ between rows, when sown in sole crops. Due to forage lodging, $U$. ruziziensis in sole crop was managed at 60 and 120 days after the emergence (DAE) of seedlings, using a Triton mechanical shredder. At 20 days before the common bean sowing, a glyphosate application (1.44 $\mathrm{kg} \mathrm{ha}^{-1}$ of a.i.) was carried out in all areas.

The common bean IPR 139 cultivar (Juriticlaro) was sown on 19 August 2010, by mechanically distributing 12 viable seeds per meter, with $0.45 \mathrm{~m}$ spacing between rows. This common bean cultivar has grains of the Carioca commercial group, cycle of 89 days, indeterminate growth habit type II, erect behavior, high yield potential and is adapted to mechanical harvest, moderately tolerant to common bacterial growth, susceptible to anthracnose and resistant to common mosaic, powdery mildew and rust (Moda-Cirino et al. 2003). The seeds received a chemical treatment with thiamethoxam $(140 \mathrm{~g} / 100 \mathrm{~kg}$ of seeds) and carbendazim + thiram $(45+105 \mathrm{~g} / 100 \mathrm{~kg}$ of seeds). In the fertilization at sowing, $4.9 \mathrm{~kg}$ of N, $49 \mathrm{~kg}$ of $\mathrm{P}_{2} \mathrm{O}_{5}$ and $49 \mathrm{~kg}$ of $\mathrm{K}_{2} \mathrm{O}$ per hectare were applied via NPK 02-20-20. Seedlings emerged at seven days after sowing, and the crop was maintained under a conventional sprinkler irrigation system, with a 4-6-day irrigation interval, applying 10-50 $\mathrm{mm}$ of water in each irrigation event, depending on the development stage of the bean crop, in order to meet the needs of the soil-plant system. At the sowing time, the temperature increased, maintaining an average of $23{ }^{\circ} \mathrm{C}$ throughout the common bean cycle. Rainfall occurred with a greater intensity from the period coinciding with the common bean flowering. In general, during the common bean cycle, there was a total rainfall of $282 \mathrm{~mm}$ and average temperature oscillating between $18{ }^{\circ} \mathrm{C}$ and $28^{\circ} \mathrm{C}$ (Figure 1).

The fluazifop-p-butyl herbicide (75 $\mathrm{g} \mathrm{ha}^{-1}$ ) was applied at 15 DAE. For the phytosanitary control, azoxystrobin $\left(40 \mathrm{~g} \mathrm{ha}^{-1}\right)$, lambda-cyhalothrin $\left(30 \mathrm{~g} \mathrm{ha}^{-1}\right)$ and abamectin $\left(5.4 \mathrm{~g} \mathrm{ha}^{-1}\right)$ were applied between 20 and $25 \mathrm{DAE}$, thiamethoxam $\left(1 \mathrm{~g} \mathrm{ha}^{-1}\right)$ and lambda-cyhalothrin $\left(10.6 \mathrm{~g} \mathrm{ha}^{-1}\right)$ at $40 \mathrm{DAE}$ and, at $65 \mathrm{DAE}$, pyraclostrobin $\left(75 \mathrm{~g} \mathrm{ha}^{-1}\right)$, deltamethrin $\left(3.5 \mathrm{~g} \mathrm{ha}^{-1}\right)$ and triazophos $\left(122 \mathrm{~g} \mathrm{ha}^{-1}\right)$.

The common bean crop was harvested at 90 DAE, and its grain yield was determined by

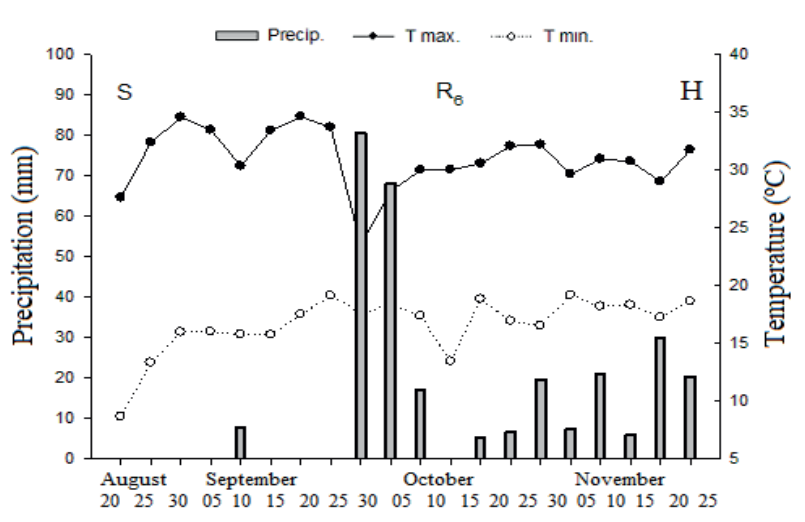

Figure 1. Precipitation, maximum and minimum temperature, average of every five days, during the common bean development period. Source: agroclimatological station of the Universidade Estadual Paulista, in Jaboticabal, São Paulo state, Brazil. S = sowing (19 August 2010); $\mathrm{R}_{6}=$ full bloom (19 October 2010); $\mathrm{H}=$ harvest (26 November 2010). 
manually collecting the plants in the evaluated area of each subplot and subsequent mechanical threshing, correcting the moisture content to $130 \mathrm{~g} \mathrm{~kg}^{-1}$ (wet basis). After the common bean harvest, grain samples from each subplot were placed in paper bags and stored for 30 days in a dry chamber at $25^{\circ} \mathrm{C}$ and $40 \%$ of relative humidity, for further evaluations of the technological attributes. In the measurement of the milling efficiency, the harvested grains were classified by size, by joint passing through sieves with oblong holes of 10/64" x 3/4" (3.97 mm x $19.05 \mathrm{~mm}), 11 / 64$ " x 3/4" (4.37 mm x $19.05 \mathrm{~mm})$, $12 / 64 " x$ 3/4" (4.76 mm x $19.05 \mathrm{~mm}), 13 / 64 " x$ 3/4" (5.16 mm x $19.05 \mathrm{~mm}), 14 / 64$ " x 3/4" (5.56 mm x $19.05 \mathrm{~mm}$ ) and 15/64" x 3/4" (5.96 mm x $19.05 \mathrm{~mm}$ ), shaking for one minute. The percentage of grains retained on each sieve and the total weight in each replicate were determined. After determining the milling efficiency, the samples of grains retained on $12 / 64 " x$ 3/4" (4.76 mm x $19.05 \mathrm{~mm}$ ) oblong holes were used to determine the other technological attributes.

The grain crude protein (CP) content was determined by $\mathrm{CP}=$ total $\mathrm{N} \times 6.25$. The cooking time (min) was measured with a Mattson cooker, with water at $96{ }^{\circ} \mathrm{C}$. For this determination, the grains were hydrated in distilled water for $12 \mathrm{~h}$. The cooking time was used to determine the level of resistance of the grains to cooking (Proctor \& Watts 1987). The grain hydration capacity was determined by the methodology described by Farinelli \& Lemos (2010), and no hard grains were detected. The hydration ratio was determined by the ratio between the final and initial mass of the grains. Analysis of polynomial regression between time (h) and hydration capacity $(\mathrm{mL})$ was applied, aiming to determine the time necessary for maximum grain hydration. In addition, the data of time for maximum grain hydration was submitted to the surface response approach.

Data were submitted to analysis of variance by the $\mathrm{F}$ test and the means compared by the Tukey test $(\mathrm{p}<0.05)$. Significant effects for $\mathrm{N}$ rates and interaction between cropping systems and $\mathrm{N}$ rates were evaluated by means of polynomial regression analysis.

\section{RESULTS AND DISCUSSION}

The crop systems and topdressing $\mathrm{N}$ rates affected the common bean grain yield, with an interaction for this variable (Table 1). In succession to intercropped corn and $U$. ruziziensis, the common bean reached an average yield of $3,025 \mathrm{~kg} \mathrm{ha}^{-1}$. In the common bean grown after $U$. ruziziensis and corn in sole crops, the maximum $\mathrm{N}$ rate applied $\left(160 \mathrm{~kg} \mathrm{ha}^{-1}\right)$ did not allow a maximum yield, with an increasing linear behavior in both situations, but with superiority after $U$. ruziziensis in sole crop (Figure 2A). When evaluating the agronomic performance of the IAC Formoso cultivar in three straw systems (sole corn, corn intercropped with $U$. ruziziensis and sole $U$. ruziziensis), and as a function of topdressing $\mathrm{N}$ fertilization $\left(0 \mathrm{~kg} \mathrm{ha}^{-1}, 40 \mathrm{~kg} \mathrm{ha}^{-1}, 80 \mathrm{~kg} \mathrm{ha}^{-1}, 120 \mathrm{~kg} \mathrm{ha}^{-1}\right.$ and $160 \mathrm{~kg} \mathrm{ha}^{-1}$ ), Cunha et al. (2015) observed higher yields in succession to $U$. ruziziensis in sole crop and intercropped with corn, with the benefits of

Table 1. Grain yield, impurities and milling efficiency obtained in grain classification by oblong-hole sieves in common bean IPR 139 (Juriti-claro) cultivar, as a function of the application of $\mathrm{N}$ rates in succession to corn and Urochloa ruziziensis in sole crops and intercropped.

\begin{tabular}{|c|c|c|c|c|c|c|c|c|c|}
\hline \multirow{3}{*}{ Treatment } & \multirow{2}{*}{ Grain yield } & \multicolumn{8}{|c|}{ Milling efficiency } \\
\hline & & Impurity & S10 & S11 & S12 & $\mathrm{S} 13$ & S14 & S15 & $>\mathrm{S} 12$ \\
\hline & $\mathrm{kg} \mathrm{ha}^{-1}$ & & & & $\%$ & & & & $\bar{z}$ \\
\hline \multicolumn{10}{|l|}{ Crop system (CS) } \\
\hline Corn & 2,816 & $7.6 \mathrm{~b}^{(1)}$ & 4.7 & 12.7 & 16.2 & 27.3 & $22.9 \mathrm{a}$ & 8.6 & 75.0 \\
\hline Corn $+U$. ruziziensis & 3,025 & $10.3 \mathrm{a}$ & 6.5 & 15.7 & 17.1 & 24.7 & $17.9 \mathrm{~b}$ & 7.8 & 67.5 \\
\hline U. ruziziensis & 3,098 & $9.6 \mathrm{a}$ & 5.5 & 15.4 & 18.1 & 26.5 & $18.1 \mathrm{~b}$ & 6.8 & 69.5 \\
\hline $\mathrm{CV}(\%)$ & 5.70 & 27.8 & 32.5 & 18.2 & 18.9 & 14.4 & 18.4 & 51.7 & 7.8 \\
\hline \multicolumn{10}{|l|}{$\mathrm{F}$ test } \\
\hline $\mathrm{CS}$ & $11.12 *$ & $4.75 * *$ & $3.38^{\mathrm{ns}}$ & $5.82^{\mathrm{ns}}$ & $1.27^{\mathrm{ns}}$ & $1.95^{\mathrm{ns}}$ & $9.02 *$ & $0.74^{\mathrm{ns}}$ & $7.47^{\mathrm{ns}}$ \\
\hline Nitrogen $(\mathrm{N})$ & $32.46^{* *}$ & $4.65^{\mathrm{ns}}$ & $1.05^{\mathrm{ns}}$ & $0.87^{\mathrm{ns}}$ & $3.03 *(2)$ & $1.40^{\mathrm{ns}}$ & $1.13^{\mathrm{ns}}$ & $0.34^{\mathrm{ns}}$ & $2.21^{\mathrm{ns}}$ \\
\hline $\mathrm{CS} \times \mathrm{N}$ & $7.65 *$ & $1.67^{\mathrm{ns}}$ & $1.39^{\mathrm{ns}}$ & $0.57^{\mathrm{ns}}$ & $0.77^{\mathrm{ns}}$ & $3.05 *$ & $1.31^{\mathrm{ns}}$ & $0.71^{\mathrm{ns}}$ & $1.18^{\mathrm{ns}}$ \\
\hline
\end{tabular}



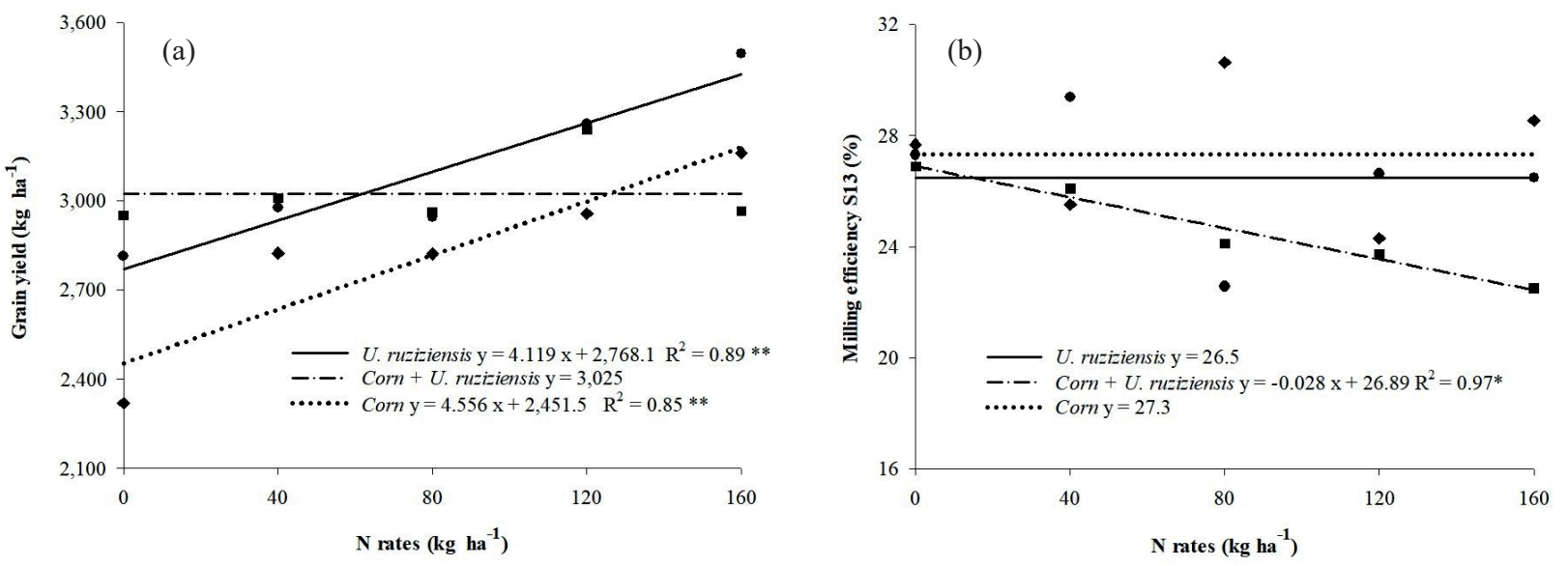

Figure 2. Grain yield (A) and milling efficiency in the sieve 13 (B) of the IPR 139 (Juriti-claro) common bean cultivar, as a function of the $\mathrm{N}$ rates in succession to corn, corn + Urochloa ruziziensis and U. ruziziensis $(\mathrm{p}<0.05)$.

obtaining straw and corn grain yield, making notillage feasible.

Research has shown the need for increasing topdressing $\mathrm{N}$ rates in common bean in succession to $U$. ruziziensis and to corn intercropped with U. ruziziensis, with a linear response up to the rate of $120 \mathrm{~kg} \mathrm{ha}^{-1}$ of N (Silveira et al. 2005). On the other hand, in a study conducted by Meira et al. (2005), the estimated topdressing $\mathrm{N}$ rate of $164 \mathrm{~kg} \mathrm{ha}^{-1}$ in common bean resulted in a maximum grain yield. In a similar study, Amaral et al. (2016) observed that $\mathrm{N}$ rates $\left(0 \mathrm{~kg} \mathrm{ha}^{-1}, 40 \mathrm{~kg} \mathrm{ha}^{-1}, 80 \mathrm{~kg} \mathrm{ha}^{-1}, 120 \mathrm{~kg} \mathrm{ha}^{-1}\right.$ and $160 \mathrm{~kg} \mathrm{ha}^{-1}$ ) had an effect on the common bean (IPR Andorinha) yield in succession to corn straw, corn intercropped with $U$. ruziziensis and U. ruziziensis. The data fitted to a quadratic model, with a maximum grain yield $\left(2,565 \mathrm{~kg} \mathrm{ha}^{-1}\right)$ obtained with the application of $136 \mathrm{~kg} \mathrm{ha}^{-1}$ of $\mathrm{N}$. In common bean in succession to corn intercropped with $U$. ruziziensis, Soratto et al. (2017) found that the supply of topdressing $\mathrm{N}$ $\left(0 \mathrm{~kg} \mathrm{ha}^{-1}, 30 \mathrm{~kg} \mathrm{ha}^{-1}, 60 \mathrm{~kg} \mathrm{ha}^{-1}, 120 \mathrm{~kg} \mathrm{ha}^{-1}\right.$ and $180 \mathrm{~kg} \mathrm{ha}^{-1}$ ) linearly increased the grain yield of the IPR 139 and Pérola cultivars by $17.3 \%$ and $52.2 \%$, respectively, regardless of the plant density ( 5 plants $\mathrm{m}^{-1}, 7$ plants $\mathrm{m}^{-1}$ and 9 plants $\mathrm{m}^{-1}$ ). Thus, although common bean has a relatively short cycle, it can be considered as a great $\mathrm{N}$ extractor. The increase in the rate of $\mathrm{N}$ immobilization by soil microorganisms due to the formation of straw on the surface may explain its high demand.

Regarding the grain classification by size, there were effects of crop system for impurities and grains retained on sieve number 14 . For the effect of $\mathrm{N}$ rates, a statistical difference was observed only in the grains retained on sieve number 12 , with an interaction also between the succession systems and $\mathrm{N}$ rates for the grains retained on sieve 13 (Figure 2B). The percentages of impurities retained at the sieve set for cultivation of $U$. ruziziensis in sole crop (9.6\%) and U. ruziziensis + corn intercropped (10.3\%) were, respectively, $20.6 \%$ and $26.6 \%$ higher, when compared to cultivation on sole corn straw (7.6\%). However, it is worth noting that the harvesting method performed in this study (manual harvest of the plants with subsequent mechanized threshing) cannot be compared to the fully mechanized harvest system (self-propelled harvesting), and further research is needed to identify possible effects of the occurrence of impurities in bean grains harvested in crop systems with different plant residues on the soil surface.

This information indicates the need of research on common bean post-harvest quality and the presence of impurities and soil aggregates, when grown in systems with a greater soil cover due to straw formation. Carmeis Filho et al. (2014), when evaluating the production components and technological quality of the IAC Formoso cultivar grown in succession to three straw production systems (sole corn, corn intercropped with $U$. ruziziensis and sole $U$. ruziziensis $)$ and topdressing $\mathrm{N}\left(0 \mathrm{~kg} \mathrm{ha}^{-1}\right.$, $40 \mathrm{~kg} \mathrm{ha}^{-1}, 80 \mathrm{~kg} \mathrm{ha}^{-1}, 120 \mathrm{~kg} \mathrm{ha}^{-1}$ and $160 \mathrm{~kg} \mathrm{ha}^{-1}$ ), verified a higher grain mass and sieve yield after U. ruziziensis.

The largest amount of grains relatively to the total, harvested in succession with sole corn, 
was retained on sieve number 14 (22.9\%), when compared to the succession with sole $U$.ruziziensis $(18.1 \%)$. Although there was no statistical difference in the milling efficiency for the sum of sieves above the number $12,75 \%$ of this yield accumulated in the system with beans in succession to sole corn, $7.3 \%$ more than the milling efficiency obtained in succession to sole $U$. ruziziensis and $10 \%$ more than in succession to corn intercropped with $U$. ruziziensis (Table 1). Milling efficiency can be an alternative in the search for better market prices, since the concept of large grains has been adopted in their commercialization. The sieve 12 is considered as a grain-size reference by bean packers, with financial rewards for suppliers who present a product with higher yield.

It should be noted that the milling efficiency above the 12 sieve, obtained for common bean as a function of topdressing $\mathrm{N}$ fertilization and cultivation in succession to corn and $U$. ruziziensis, in sole crops or intercropped, corresponded to $75 \%, 69.5 \%$ and $67.5 \%$, respectively (Table 1 ). An increase in common bean grain size as a function of topdressing $\mathrm{N}$ was reported by Crusciol et al. (2003), showing a significant effect with the $\mathrm{N}$ rate of $25 \mathrm{~kg} \mathrm{ha}^{-1}$, which led to a percentage reduction in the number of seeds retained on the sieves 14 and 15, thus increasing the proportion of grains retained on the sieves number 17 and 18.

For the effect of $\mathrm{N}$ rates on the grain size of common bean in succession to corn and $U$.ruziziensis, a statistical difference occurred only in the milling efficiency obtained in the sieve 12 , and the $\mathrm{N}$ rate of $80 \mathrm{~kg} \mathrm{ha}^{-1}$ caused a $9.7 \%$ reduction in grains retained on this sieve, if compared to the overall average. In addition, for the effect of topdressing $\mathrm{N}$ rates on the milling efficiency above the sieve 12 , values around $70 \%$ were observed (Table 1 ).

Data on crude protein content, cooking time and moisture content in common bean grains are presented in Table 2 . The grain crude protein content was not influenced by the $\mathrm{N}$ fertilization on common bean grown in succession to corn and U. ruziziensis in sole crops or intercropped. Concerning the cooking time, there were individual effects for $\mathrm{N}$ rates and crop systems. There was an interaction between crop systems and $\mathrm{N}$ rates for the hydration ratio. The grain crude protein content is one of the factors that contribute to the high consumption of this food in the basic diet of Brazilians. According to Moda-Cirino et al. (2003), this common bean cultivar has a protein potential around $230 \mathrm{~g} \mathrm{~kg}^{-1}$, a value close to those obtained in the present experiment. The grain crude protein content was not influenced by the studied factors (Table 2), i.e., even without the topdressing $\mathrm{N}$, there was an adequate supply of this nutrient to the crop. According to Silveira et al. (2005), although large amounts of $\mathrm{N}$ are contained in the shoot of the so-called soil cover crops, the actual amount of $\mathrm{N}$ assimilated by the crop in succession will depend on the timing between the straw decomposition and the demand rate of the successor crop. Despite the short cycle of common bean plants, it is probable that the decomposition of the straw in the study will have met their needs for N, as indicated by Amaral et al. (2016).

The grain crude protein content can demonstrate the adequate nutrition of plants (Fornasieri Filho et al. 2007), indicating that there was a translocation of this nutrient in the source/sink ratio, i.e., from the leaves to the grains, evidencing the hypothesis that the degradation and decomposition of the straw produced by the summer crops, besides the biological fixation of atmospheric $\mathrm{N}$, can contribute to the supply of $\mathrm{N}$ to the common bean. Farinelli \& Lemos (2010) observed a linear response for the grain crude protein content as a function of the topdressing $\mathrm{N}$ on common bean, obtaining an increase of $3.5 \%$ with the application of $120 \mathrm{~kg} \mathrm{ha}^{-1}$. Other researchers noticed increases in this component due to topdressing $\mathrm{N}$ (Amaral et al. 2016), confirming the hypothesis that the $\mathrm{N}$ application in common bean may influence

Table 2. Grain crude protein content, cooking time and hydration ratio in common bean IPR 139 (Juriti-claro) cultivar, as a function of the application of $\mathrm{N}$ rates in succession to corn and Urochloa ruziziensis in sole crops and intercropped.

\begin{tabular}{|c|c|c|c|}
\hline \multirow[t]{2}{*}{ Treatment } & $\begin{array}{c}\text { Grain crude } \\
\text { protein }\end{array}$ & $\begin{array}{l}\text { Cooking } \\
\text { time }\end{array}$ & \multirow{2}{*}{$\begin{array}{l}\text { Hydration } \\
\text { ratio }\end{array}$} \\
\hline & $\mathrm{g} \mathrm{kg}^{-1}$ & $\min$ & \\
\hline \multicolumn{4}{|l|}{ Crop system (CS) } \\
\hline Corn & 224.8 & $35.0 \mathrm{a}^{(1)}$ & 1.97 \\
\hline Corn $+U$. ruziziensis & 224.4 & $40.4 \mathrm{~b}$ & 1.96 \\
\hline U. ruziziensis & 217.5 & $33.2 \mathrm{a}$ & 1.98 \\
\hline $\mathrm{CV}(\%)$ & 5.36 & 11.92 & 0.75 \\
\hline \multicolumn{4}{|l|}{ F test } \\
\hline $\mathrm{CS}$ & $1.79^{\mathrm{ns}}$ & $11.20^{*}$ & $3.36^{\mathrm{ns}}$ \\
\hline Nitrogen $(\mathrm{N})$ & $0.48^{\mathrm{ns}}$ & $2.96^{*}$ & $1.04^{\mathrm{ns}}$ \\
\hline $\mathrm{CS} \times \mathrm{N}$ & $1.36^{\mathrm{ns}}$ & $0.79^{\text {ns }}$ & $2.67 *$ \\
\hline
\end{tabular}


the grain protein content. Gomes Junior \& Sá (2010) verified that the application of up to $120 \mathrm{~kg} \mathrm{ha}^{-1}$ of N in both the $\mathrm{V}_{4-3}$ and $\mathrm{V}_{4-6}$ stages promoted an increase in the grain crude protein content, and the mean values for the zero rate were $18.4 \%$ and $17.3 \%$, while, for the rate of $120 \mathrm{~kg} \mathrm{ha}^{-1}$ of $\mathrm{N}$, the contents were $22.7 \%$ and $21.3 \%$ for the cultivars IPR Juriti and Pérola, respectively, in no-tillage system under millet straw.

The grain cooking time varied among the cropping systems to which the common bean was subjected (Table 2). In succession to corn and $U$. ruziziensis in sole crops, the grain cooking times did not differ, but they stood out from those of the succession to the intercropping, since this system led to the longest cooking time for the grains produced. In succession to U. ruziziensis and corn in sole crops, the grains were characterized as resistant to cooking, ranging 33-36 min., while grains of common beans cultivated after corn and $U$. ruziziensis intercropped exceeded 36 min for cooking, being classified as highly resistant (Proctor \& Watts 1987). Increasing the topdressing $\mathrm{N}$ rates caused a decrease in the grain cooking time, a linear behavior for this technological attribute (Figure 3). These results corroborate those of Farinelli \& Lemos (2010) and Carmeis Filho et al. (2014). In this case, there may have been an increase in the number of leaves in the common bean as a function of the $\mathrm{N}$ rates, influencing the physiological maturity, specifically in the water loss process,

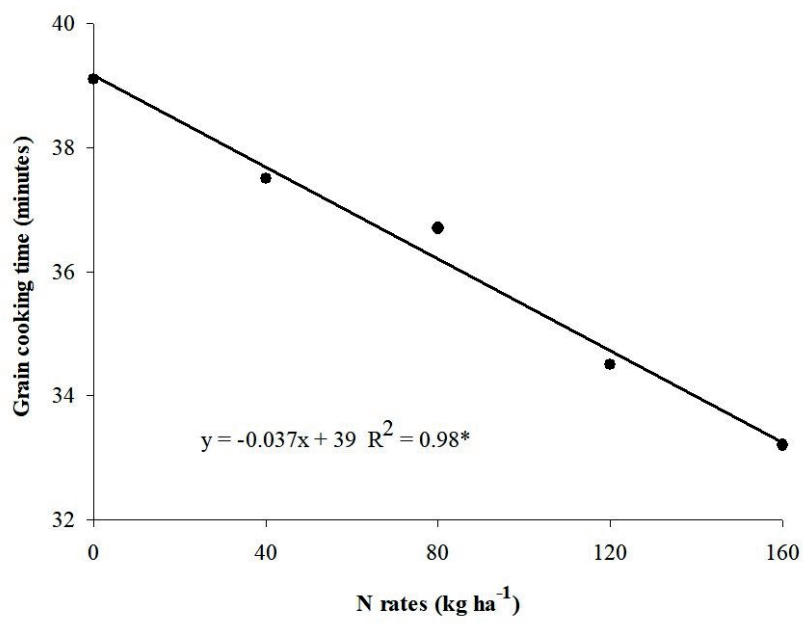

Figure 3. Grain cooking time for the IPR 139 (Juriti-claro) common bean cultivar, as a function of the $\mathrm{N}$ rates, in succession to corn and Urochloa ruziziensis $(\mathrm{p}<$ $0.05)$. leading to a decrease in the grain cooking time. In addition, climatic factors such as rainfall events at harvest may influence this attribute.

On average, the grain hydration ratio was close to 2, showing that the grains absorbed twice their mass in water, corroborating the observations of Lemos et al. (2004). It is worth noting that hardshell grains were not detected. This is probably due to the interactions between the genetic material and the growing environment, since the occurrence of hard grains is caused by situations of water stress and high temperatures close to the harvest season (Carbonell et al. 2003). The analysis of the interaction between cropping systems and $\mathrm{N}$ rates for the common bean hydration ratio is presented in Figure 4. It should be noted that, for the crop systems containing sole corn and corn intercropped with U. ruziziensis, the hydration ratio of the bean grains remained constant, even with the application of topdressing N. In bean grains produced under straw of $U$. ruziziensis in sole crop, the grain hydration ratio decreased as the topdressing $\mathrm{N}$ rate increased.

There were no differences between the time for maximum grain hydration due to the crop systems and the topdressing $\mathrm{N}$ rates applied (Table 3 ), as observed in the response surface approach (Figure 5). Contrary to Silva et al. (2006), who obtained increasing values above $12 \mathrm{~h}$, with $\mathrm{N}$ applications (0-120 $\left.\mathrm{kg} \mathrm{ha}^{-1}\right)$ in the Pérola cultivar, in the present study, the maximum grain hydration time, on average, was

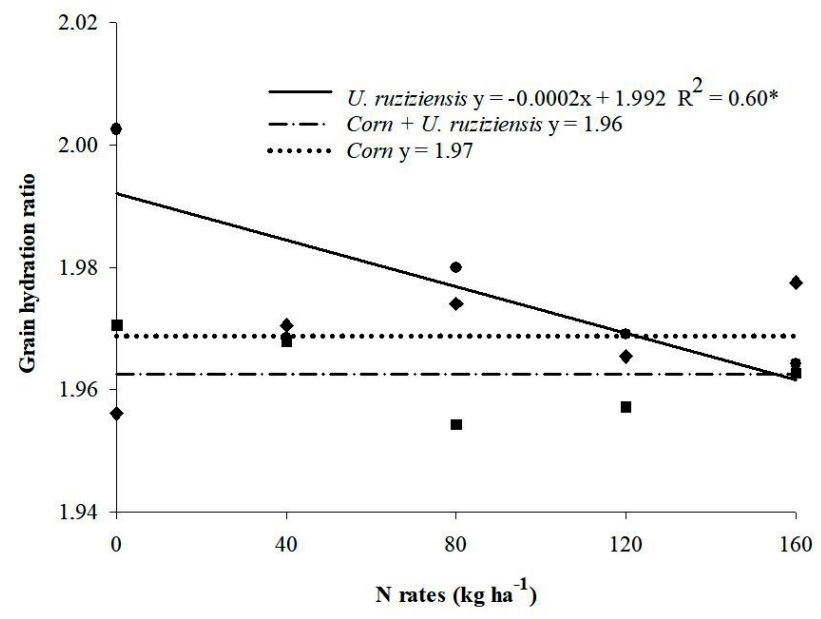

Figure 4. Grain hydration ratio for the IPR 139 (Juriti-claro) common bean cultivar, as a function of the $\mathrm{N}$ rates, in succession to corn, corn + Urochloa ruziziensis and U. ruziziensis $(\mathrm{p}<0.05)$. 
Table 3. Maximum grain hydration time (HT $=\mathrm{h}: \mathrm{min}$ ) for the IPR 139 (Juriti-claro) common bean cultivar, as a function of the application of $\mathrm{N}$ rates in succession to corn and Urochloa ruziziensis in sole crops and intercropped.

\begin{tabular}{|c|c|c|c|c|}
\hline \multicolumn{2}{|c|}{ Treatment } & \multirow{2}{*}{ Regression equation $^{(1)}$} & \multirow{2}{*}{$\mathrm{R}^{2}$} & \multirow{2}{*}{ HT } \\
\hline Crop system & $\mathrm{N}$ rates $\left(\mathrm{kg} \mathrm{ha}^{-1}\right)$ & & & \\
\hline \multirow{5}{*}{ Corn } & 0 & $y=-0.0001 x^{2}+0.1350 x+14.574$ & 0.77 & $11: 15$ \\
\hline & 40 & $y=-0.0001 x^{2}+0.1342 x+15.206$ & 0.75 & $11: 11$ \\
\hline & 80 & $y=-0.0001 x^{2}+0.1314 x+14.362$ & 0.78 & $10: 57$ \\
\hline & 120 & $y=-0.0001 x^{2}+0.1266 x+14.181$ & 0.78 & $10: 33$ \\
\hline & 160 & $y=-0.0001 x^{2}+0.1366 x+14.373$ & 0.79 & $11: 23$ \\
\hline \multirow{5}{*}{ Corn $+U$. ruziziensis } & 0 & $y=-0.0001 x^{2}+0.1356 x+12.764$ & 0.83 & $11: 18$ \\
\hline & 40 & $y=-0.0001 x^{2}+0.1397 x+13.360$ & 0.82 & $11: 38$ \\
\hline & 80 & $y=-0.0001 x^{2}+0.1370 x+12.556$ & 0.83 & $11: 25$ \\
\hline & 120 & $y=-0.0001 x^{2}+0.1361 x+12.464$ & 0.83 & $11: 20$ \\
\hline & 160 & $y=-0.0001 x^{2}+0.1351 x+13.265$ & 0.81 & $11: 15$ \\
\hline \multirow{5}{*}{ U. ruziziensis } & 0 & $y=-0.0001 x^{2}+0.1375 x+11.922$ & 0.86 & $11: 27$ \\
\hline & 40 & $y=-0.0001 x^{2}+0.1278 x+11.101$ & 0.87 & $10: 39$ \\
\hline & 80 & $y=-0.0001 x^{2}+0.1410 x+12.588$ & 0.84 & $11: 45$ \\
\hline & 120 & $y=-0.0001 x^{2}+0.1337 x+12.944$ & 0.82 & 11:08 \\
\hline & 160 & $y=-0.0001 x^{2}+0.1340 x+11.452$ & 0.86 & $11: 10$ \\
\hline
\end{tabular}

${ }^{(1)} \mathrm{x}=$ time for hydration $(\mathrm{min})$ and $\mathrm{y}=$ amount of water absorbed $(\mathrm{mL}) . \mathrm{R}^{2}=$ coefficient of determination.

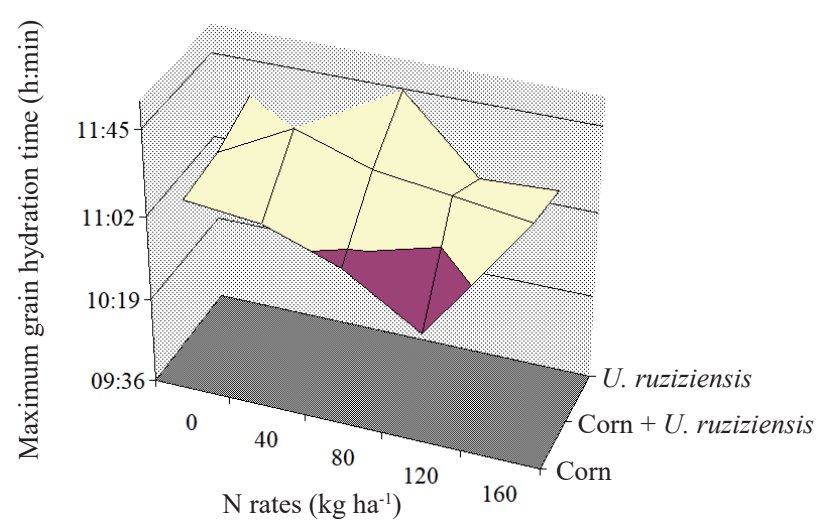

Figure 5. Surface response approach for the maximum grain hydration time of the IPR 139 (Juriti-claro) common bean cultivar, as a function of the nitrogen rates in succession to corn, corn + Urochloa ruziziensis and U. ruziziensis $(\mathrm{p}<0.05)$.

less than $12 \mathrm{~h}$. The imbibition time for maximum grain hydration ranged from $10 \mathrm{~h}$ and $10 \mathrm{~min}$ to $11 \mathrm{~h}$ and $45 \mathrm{~min}$ and may be considered adequate, since, in the Brazilian cuisine, beans are generally immersed in water the night before preparation or cooking. The time for maximum grain hydration may vary depending on the genetic material, growing environment and storage conditions (Carbonell et al. 2003, Dalla Corte et al. 2003, Lemos et al. 2004). However, the need for improvements in scientific research on the influence of $\mathrm{N}$ fertilization on this technological attribute is evident.

\section{CONCLUSIONS}

1. There is an interaction between predecessor cropping systems and nitrogen rates for grain yield, milling efficiency specifically on sieve 13 , as well as grain hydration ratio;

2. Increasing the topdressing $\mathrm{N}$ rates applied on common bean in succession to sole corn crop promotes increases in grain yield, resulting in a higher milling efficiency in the oblong-hole sieve 14, when compared to the other crop systems evaluated;

3. The increase of $\mathrm{N}$ rates applied on common bean in succession to corn and U. ruziziensis in sole crops or intercropped does not influence the time for maximum grain hydration, but reduces the time required for cooking.

\section{REFERENCES}

AMARAL, C. B. et al. Produtividade e qualidade do feijoeiro cultivado sobre palhadas de gramíneas e adubado com nitrogênio em plantio direto. Pesquisa Agropecuária Brasileira, v. 51, n. 9, p. 1602-1609, 2016.

CARBONELl, S. A. M.; CARVALHO, C. R. L.; PEREIRA, V. R. Qualidade tecnológica de grãos de genótipos de feijoeiro cultivados em diferentes ambientes. Bragantia, v. 62, n. 3, p. 369-379, 2003.

CARMEIS FILHO, A. C. A. et al. Adubação nitrogenada no feijoeiro após palhada de milho e braquiária no plantio direto. Revista Caatinga, v. 27, n. 2, p. 66-75, 2014. 
CRUSCIOL, C. A. C. et al. Efeito do nitrogênio sobre a qualidade fisiológica, produtividade e características de sementes de feijão. Revista Brasileira de Sementes, v. 25, n. 1, p. 108-115, 2003.

CUNHA, T. P. L. et al. Agronomic performance of common bean in straw mulch systems and topdressing nitrogen rates in no-tillage. Revista Ceres, v. 62, n. 5, p. 489-495, 2015.

DALLA CORTE, A. et al. Environment effect on grain quality in early common bean cultivars and lines. Crop Breeding and Applied Biotechnology, v. 3, n. 3, p. 193202, 2003.

FARINELLI, R.; LEMOS, L. B. Produtividade, eficiência agronômica, características nutricionais e tecnológicas do feijão adubado com nitrogênio em plantio direto e convencional. Bragantia, v. 69, n. 1, p. 165-172, 2010.

FORNASIERI FILHO, D. et al. Resposta de cultivares de feijoeiro comum à adubação nitrogenada em sistema de plantio direto. Cientifica, v. 35, n. 2, p. 115-121, 2007.

GOMES JUNIOR, F. G.; SÁ, M. E. Proteína e qualidade de sementes de feijão (Phaseolus vulgaris L.) em função da adubação nitrogenada em plantio direto. Revista Brasileira de Sementes, v. 32, n. 1, p. 34-44, 2010.

LEMOS, L. B. et al. Características agronômicas e tecnológicas de genótipos de feijão do grupo comercial Carioca. Pesquisa Agropecuária Brasileira, v. 39, n. 4, p. 319-326, 2004.

MEIRA, F. A. et al. Doses e épocas de aplicação de nitrogênio no feijoeiro irrigado cultivado em plantio direto. Pesquisa Agropecuária Brasileira, v. 40, n. 4, p. 383-388, 2005.
MINGOTTE, F. L. C. et al. Desempenho produtivo e qualidade pós-colheita de genótipos de feijão do grupo comercial Carioca cultivados na época de invernoprimavera. Bioscience Journal, v. 29, n. 5, p. 1101-1110, 2013.

MINGOTTE, F. L. C.; LEMOS, L. B. Rotação e sucessão de culturas: formação de palha para o sistema plantio direto de qualidade no Cerrado. Informe Agropecuário, v. 39, n. 302, p. 28-41, 2018.

MODA-CIRINO, V. et al. IPR Juriti: common bean cultivar. Crop Breeding and Applied Biotechnology, v. 3, n. 4, p. 303-306, 2003.

PROCTOR, J. R.; WATTS, B. M. Development of a modified Mattson bean cooker procedure based on sensory panel cookability evaluation. Canadian Institute of Food Science and Technology Journal, v. 20, n. 1, p. 9-14, 1987.

RODRIGUES, J. A. et al. Correlação entre absorção de água e tempo de cozimento de cultivares de feijão. Ciência Rural, v. 35, n. 1, p. 209-214, 2005.

SILVA, T. R. B.; LEMOS, L. B.; TAVARES, C. A. Produtividade e característica tecnológica de grãos em feijoeiro adubado com nitrogênio e molibdênio. Pesquisa Agropecuária Brasileira, v. 41, n. 5, p. 739-745, 2006.

SILVEIRA, P. M. et al. Adubação nitrogenada no feijoeiro cultivado sob plantio direto em sucessão de culturas. Pesquisa Agropecuária Brasileira, v. 40, n. 4, p. 377381, 2005.

SORATTO, R. P. et al. Plant density and nitrogen fertilization on common bean nutrition and yield. Revista Caatinga, v. 30, n. 3, p. 670-678, 2017. 